\title{
Development of Pre- and Postharvest Phytophthora Fruit Rot on Watermelons Treated with Fungicides in the Field
}

\begin{abstract}
Chandrasekar S. Kousik, Jennifer L. Ikerd, and Howard F. Harrison, U.S. Vegetable Laboratory, USDA-ARS, 2700 Savannah Highway,
\end{abstract} Charleston, SC 29414, USA

Accepted 25 August 2014. 29 September 2014.

\section{ABSTRACT}

Kousik, C. S., Ikerd, J. L., and Harrison, H. F. 2014. Development of pre- and postharvest Phytophthora fruit rot on watermelons treated with fungicides in the field. Plant Health Progress doi:10.1094/PHP-RS-14-0025.

Fruit rot, caused by Phytophthora capsici, is a serious disease in most watermelon producing regions in the southeastern United States and has caused devastating losses over the past few years. Experiments were conducted from 2010 to 2013 in a $P$. capsici-infested field to identify fungicides effective for managing pre- and postharvest development of Phytophthora fruit rot. Weekly treatments of OXTP (Oxathiapiprolin), V-10208 (ethaboxam), Zampro (ametoctradin+dimethomorph), Forum (dimethomorph), Prophyt (potassium phosphite) + Kocide 2000 (copper hydroxide), Revus (mandipropamid) rotated with Prophyt + Kocide, and rotations of Revus with Presidio (fluopicolide) and Actigard with Revus

\section{INTRODUCTION}

Phytophthora fruit rot of watermelon (Citrullus lanatus var. lanatus) caused by Phytophthora capsici, is a serious disease in much of the southeastern United States, especially in North and South Carolina, Georgia, and Florida (Figs. 1 and 2). Over $50 \%$ of U.S. watermelons (USDA-NASS, Vegetables 2012 summary) are produced in the southeastern states (Florida, Georgia, South Carolina, North Carolina, and Virginia), where weather conditions are often favorable for the development of Phytophthora fruit rot throughout the growing season. In 2012, about 70,000 acres of watermelon were planted in the major watermelon producing states in the southeast. Of these, North Carolina (8,400 acres), South Carolina (8000 acres), Georgia (26,000 acres), and Florida $(26,500)$ can be considered important watermelon producing states (USDA-NASS, Vegetables 2012 summary). Between 2003 and 2010, we observed several watermelon farms in Georgia, South Carolina, and North Carolina where the crop was partially or never harvested due to severe fruit rot. Many growers also suffered severe postharvest losses caused by the pathogen rotting the fruit during storage and transportation. These instances of severe preand postharvest losses led the National Watermelon Association, a grower's consortium, to rank Phytophthora fruit rot as a top research priority in 2006 (17) and again in 2013 and 2014.

Corresponding author: C. S. Kousik (Shaker). Email: shaker.kousik@ars.usda.gov

doi:10.1094/PHP-RS-14-0025

This article is in the public domain and not copyrightable. It may be freely reprinted with customary crediting of the source. The American Phytopathological, 2014. significantly reduced preharvest fruit rot in the field compared to nontreated control. Symptomless fruit harvested four days after the last spray was inoculated with $P$. capsici and maintained in a humid chamber to evaluate postharvest fruit rot development. OXTP, Zampro, Forum, V-10208, Presidio rotated with Revus, and Actigard rotated with Revus applied in the field provided extended postharvest protection compared to nontreated control. Many of these fungicides belonging to different FRAC group should be used in rotations to manage Phytophthora fruit rot of watermelon and should be part of an overall management strategy that also includes use of well drained fields and proper irrigation practices.

Phytophthora capsici is distributed worldwide and has been reported to infect plants belonging to 27 families $(3,4,5)$. The pathogen also causes serious losses in a wide variety of vegetable crops in the families Solanaceae (tomato, pepper, eggplant); Cucurbitaceae (cucumber, watermelon, squash, pumpkin, melon); and Fabaceae (snap bean) $(3,4,5)$. Phytophthora capsici can infect most parts of the plant and cause a wide variety of symptoms, including leaf blight and fruit and crown rots on cucurbits and other crops $(4,5)$. Various strategies are recommended to manage $P$. capsici in the field, including: cultural practices that ensure well-drained soils; crop rotation; soil solarization; reducing splash dispersed soil; and various chemical controls $(2,5,11,15,20)$. Crop rotation may be ineffective in farms where both mating types of the pathogen are present, as the oospores of $P$. capsici can persist in the soil for many years $(4,14)$. Other strategies to manage diseases caused by $P$. capsici include the use of mustard cover crop $(7,16,19)$ and application of chicken manure $(18,22)$ which are reported to reduce disease pressure by decreasing pathogen populations in the field.

Regular application of fungicides is often the most recommended strategy for managing vegetable diseases caused by $P$. capsici. Fungicides with different modes of action are effective for managing preharvest Phytophthora fruit rot of watermelon (11). However, because the emergence of fungicide resistant strains is a constant threat, new fungicides and additional strategies are needed to manage diseases caused by $P$. capsici. Furthermore, the effectiveness of these fungicides against postharvest disease development is not known. The present study was conducted from 2010 to 2013 to determine the effectiveness of Actigard, a systemic resistance activator (SAR), other new fungicides, and simple fungicide rotation schemes to manage pre- and postharvest Phytophthora fruit rot of watermelon. 


\section{PLANTING, PREHARVEST FUNGICIDE APPLICATIONS, AND INOCULATION}

All experiments were conducted at the U.S. Vegetable Laboratory Farm in Charleston, SC, where the soil is Yonges loamy fine sand (typic Endoaqualfs). Trials were conducted in a field infested with $P$. capsici for the previous three years. The experimental design was a randomized complete block with four replications in all these years (2010, 2011, and 2013). Four-week-old seedlings of the susceptible seedless (triploid) cultivar Vanessa and the diploid (seeded) cultivar Mickey Lee were grown in 50-cell jiffy trays and transplanted onto raised beds with $1.02-\mathrm{m}$ (40-inch) centers. Every fourth plant in the plot was Mickey Lee which served as the pollenizer. Seedlings were transplanted on 30 June in 2010, 6 July in 2011, and 12 June in 2013. Beds were spaced $6.4 \mathrm{~m}(21 \mathrm{ft})$ apart and covered with white plastic mulch. Plots were a single row of 12 plants spaced $46 \mathrm{~cm}$ apart with 4.6- $\mathrm{m}$ spacing between plots. Plants were irrigated as needed using drip irrigation. After bedding, but before planting, row middles were sprayed with Roundup Pro (1.17 liter/ha) and Strategy (2.24 liter/ha) for weed management. During the growing season, weeds between

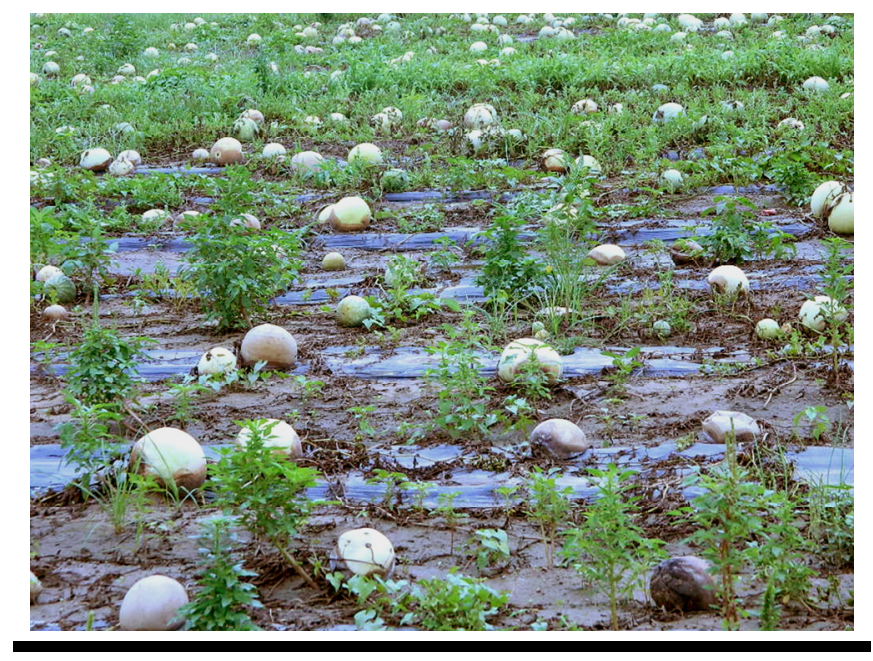

FIGURE 1

A commercial watermelon field in the southeastern United States devastated by fruit rot caused by the pathogen Phytophthora capsici. The grower had to abandon this field due to severe preharvest and postharvest fruit rot.

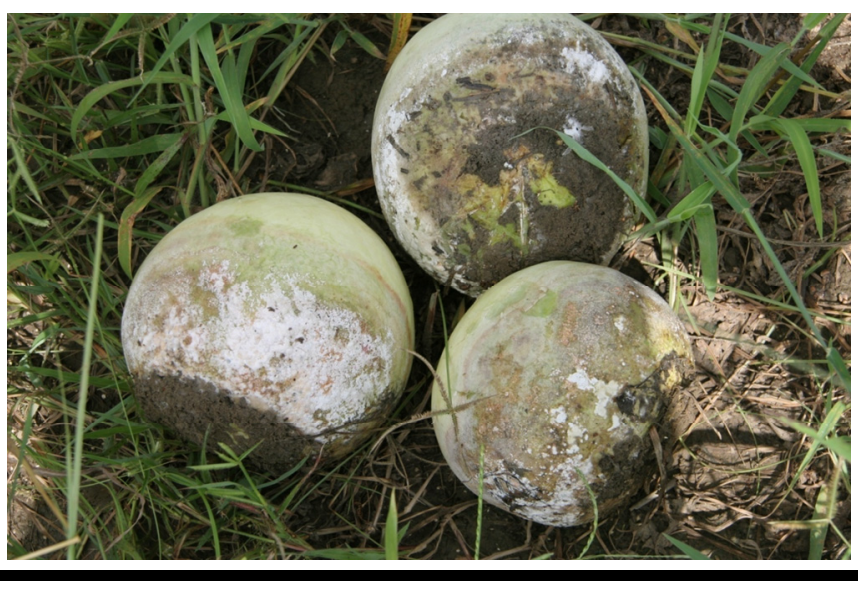

FIGURE 2

Close up of severe fruit rot caused by Phytophthora capsici on 'Mickey Lee' watermelon fruit ('Mickey Lee' was used as pollenizer in the trials). The white powdered sugar-like growth seen on the fruit is primarily $P$. capsici sporangia on the rotting fruits. beds were controlled with spot application of Roundup. For each year the experiment was conducted, watermelon plants were maintained using standard practices for South Carolina $(9,21)$. A similar experiment was also conducted in 2012, but disease development in nontreated control plots was not adequate to evaluate fungicide efficacy and moreover plant growth and development was poor. Therefore, details from 2012 were not included.

All fungicide treatments were applied using a $\mathrm{CO}_{2}$-pressurized backpack sprayer calibrated to deliver 290 liters/ha using a handheld boom equipped with 3 nozzles (flat fan, Teejet 8002VS) spaced 48 $\mathrm{cm}$ apart. The first fungicide application was made when most of the watermelon fruit were about $8-10 \mathrm{~cm}$ in diameter. Since watermelon fruit are susceptible to $P$. capsici at all developmental stages (1), subsequent applications were made at weekly intervals. In 2010, fungicides were applied on 5, 13, 19, and 27 August and 3 September for a total of five applications. In 2011, fungicides were applied on 5, 16, 23, and 30 August, and in 2013 on 18 , and 25 July, and 1, 8, and 19 August. The details of the fungicides applied, their formulations, active ingredients, and rate are presented in Table 1.

To enhance disease development, watermelon plants in all the plots were inoculated about two weeks after the start of spray treatments. Each year, mefenoxam sensitive and insensitive isolates were grown on rice grains soaked in V8 juice in wide-mouth mason jars for a month. The isolates were grown individually and mixed prior to uniformly spreading them by hand scattering (122 grams/plot) in each plot as described previously (11). Field plots were inoculated on 26 August in 2010, 18 August in 2011, and 24 July in 2013. During 2010, 2011, and 2013 weather conditions were favorable for disease development and inoculations were done on days when rain was predicted. In 2010, the total rainfall from the time of transplanting to final rating was 12.06 inches and rainfall from the start of spray treatments on 5 August to final rating on 7 September was 7.04 inches. In 2011, the total rainfall from the time of transplanting to final rating was 11.45 inches. and rainfall from the start of spray treatments on 5 August to final rating on 30 August was 5.95 inches. Total rainfall in 2013 from the time of transplanting to final rating was 17.9 inches, and rainfall from the start of spray treatments on 18 July to final rating on 23 August was 7.7 inches. The total number of marketable watermelon fruit and the number of marketable-sized rotten fruit in each plot were recorded at end of the experiment. Total fruits and number of rotted fruits per plot were recorded on 7 September in 2010, 30 August in 2011 and 23 August in 2013. Fruit rot incidence was calculated as the number of rotted fruits in a plot divided by the total number of fruits in the plot. If the assumptions of homogeneity of variance could not be met the (percent fruit rot) data were transformed to arcsine values and analyzed using Proc GLM procedure of SAS (SAS Institute Inc., Cary, NC). Means were separated using the Fisher's protected Least Significant Difference (LSD, $\alpha=0.05$ ) procedure of SAS. Disease reduction due to the various fungicide treatments was calculated relative to the mean disease in the nontreated control for each year. Data points for each year were used as a replication and the mean effectiveness of the various fungicide treatments were calculated across years using the percent disease reduction data. Year was included as a factor in the analysis. The percent disease reduction data from each year were transformed to arcsine values and analyzed using Proc GLM procedure of SAS. Means were separated using the Fisher's protected Least Significant Difference (LSD, $\alpha=0.05$ ) procedure of SAS.

\section{PREHARVEST PHYTOPHTHORA FRUIT ROT DEVELOPMENT IN THE FIELD}

Phytophthora fruit rot development was severe in the three years (2010, 2011, and 2013) in the nontreated control plots indicating that experiments were useful for evaluation of fungicide treatments. 
Highly significant differences were observed among the fungicide treatments (Table 2). OXTP (oxathiapiprolin) was one of the most effective treatments in reducing Phytophthora fruit rot in the field (Table 2). Similarly ethaboxam (V-10208) and the rotation of Presidio (fluopicolide) and Revus (mandipropamid) were also highly effective in reducing fruit rot and not significantly different from OXTP when compared over three years (Table 2). Forum, Zampro, Prophyt + Kocide, and Revus rotated with Prophyt + Kocide treatments also significantly reduced fruit rot compared to nontreated control. Application of Actigard every week significantly reduced fruit rot in 2010 but not in 2011 or 2013. Rotation of Actigard with Revus or Presidio also significantly reduced fruit rot in 2011 and 2013 compared to nontreated control. Ridomil Gold treatment was not significantly different from the nontreated control in 2010. In 2011 and 2013, Ridomil Gold treatments reduced fruit rot significantly compared to the control.
However, it was not as effective as some of the other fungicide treatments. This was expected, because mefenoxam insensitive strains were included as a part of the inoculum. Total numbers of fruit per plot were not significantly different among the fungicide treatments in all three years (data not presented), indicating that application of Actigard to watermelon after fruit formation may be considered in fruit rot management plans. Phytotoxicity due to the fungicide treatments was not observed on the plant foliage in the three trials.

\section{POSTHARVEST PHYTOPHTHORA FRUIT ROT EVALUATION}

Four to five symptomless fruits were harvested from each plot of the experiments discussed above four days after the last spray treatment, and placed on wire shelves in a sealed room. Symptomless fruit were inoculated on 8 September in 2010, 3 September in 2011, and 23 August in 2013. Each fruit was inoculated in the

\begin{tabular}{|c|c|c|c|c|}
\hline \multicolumn{5}{|c|}{$\begin{array}{l}\text { TABLE } 1 \\
\text { Details of fungicides used in the study for managing pre- and postharvest Phytophthora fruit rot of watermelon. }\end{array}$} \\
\hline $\begin{array}{l}\text { Trade name and } \\
\text { formulation } w\end{array}$ & Manufacturer & Active Ingredient (a.i. $)^{x}$ & FRAC Codey & $\begin{array}{l}\text { Application Rate } \\
\text { (product/ha) }\end{array}$ \\
\hline V-10208 & Valent & ethaboxam & 22 & $280 \mathrm{~g}$ a.i \\
\hline Actigard & Syngenta & acibenzolar-S-methyl & $\mathrm{P} 1$ & $70 \mathrm{~g}$ \\
\hline Zampro & BASF & ametoctradin/dimethomorph & $45 / 40$ & 1.02 liter \\
\hline Revus 2.08SC & Syngenta & mandipropamid & 40 & 0.59 liter \\
\hline Presidio 4FL & Valent & fluopicolide & 43 & 0.29 liter \\
\hline Prophyt 4L & Helena & potassium phosphite & 33 & 1.17 liter \\
\hline Kocide 2000 54DF & DuPont & copper hydroxide & M1 & $1.68 \mathrm{~kg}$ \\
\hline
\end{tabular}

${ }^{\mathrm{w}}$ Activator 90 (0.1\%) was added to all the Revus treatments.

$\mathrm{x}$ The details of the active ingredients including concentrations present in each of the fungicides can be obtained from the appropriate fungicide label.

y FRAC $=$ Fungicide Resistance Action Committee. The FRAC code list can be obtained online at www.frac.info/frac/menu.htm.

z OXTP (oxathiapiprolin) belongs to the piperidinyl thiazole isoxazoline class of fungicides and has a novel mode of action. It does not belong to any of the currently described FRAC codes. OXTP is distributed by Syngenta in the United States. Its DuPont designated experimental code in the United States is DPX-QGU42 and is also known as Zorvec.

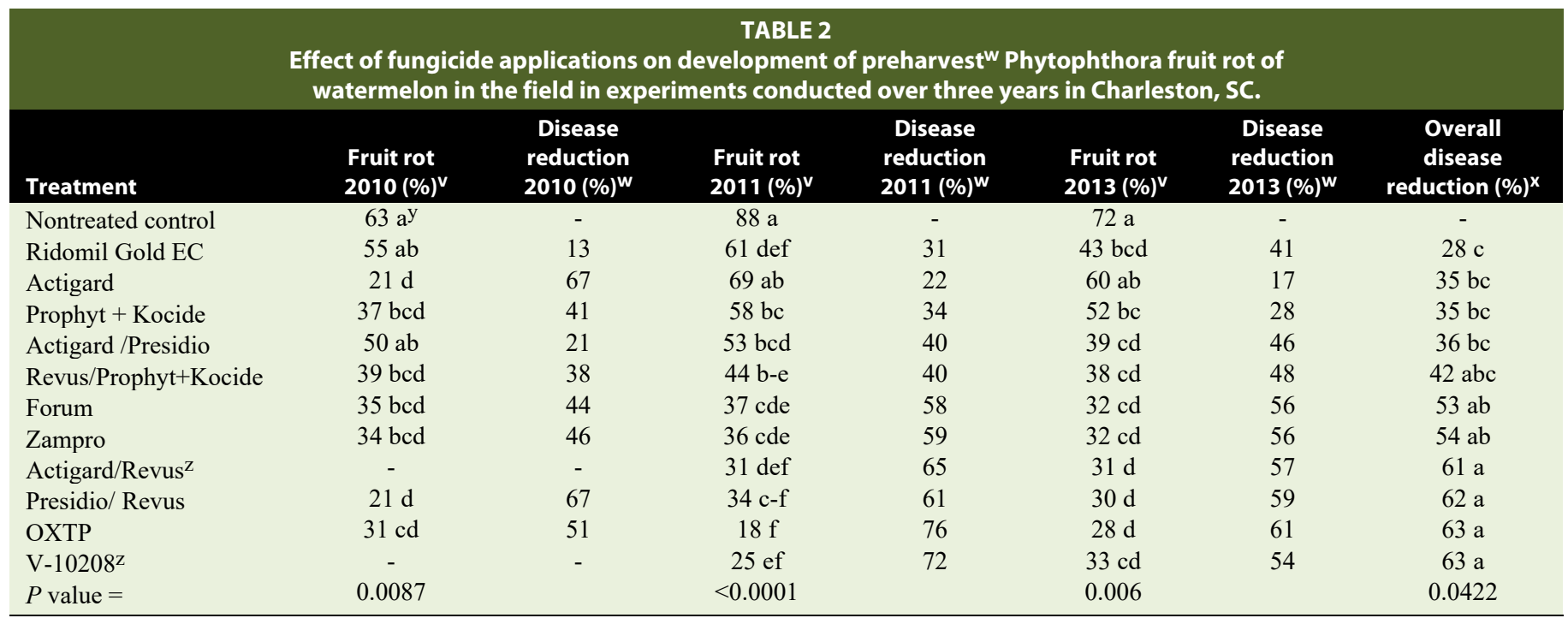

v Preharvest fruit rot incidence is based on number of fruits rotted/total number of fruits in the plot. Application rates are provided in Table 1. A "/" between two fungicides in the treatment column indicates a rotation scheme. The fungicides were alternated every week. The fungicide named first before the "/ "was applied first in the rotation scheme.

wPercent disease reduction for each year was calculated on the basis of mean fruit rot incidence for the nontreated control as shown in Table 2.

$\mathrm{x}$ Overall disease reduction is a mean of the three years.

$\mathrm{y}$ Means followed by same letter within column are not significantly different based on Fisher's protected LSD test $(\alpha=0.05)$.

z V-10208 and Actigard/Revus were not evaluated in 2010. 
center by placing a 7-mm agar plug from a 3-day-old actively growing isolate of $P$. capsici. The agar plug was gently placed on the fruit surface without any injury (Fig. 3). The isolate used was insensitive to mefenoxam. After inoculation, high relative humidity $(>95 \%)$ was maintained in the room using a humidifier and the temperature was maintained at $26 \pm 2{ }^{\circ} \mathrm{C}$. To enhance pathogen sporulation, the room was continuously illuminated using florescent lamps $(12,13)$. Five days after inoculation, the lesion diameter on each fruit was measured with the agar plug considered as the lesion center (Fig. 3). Similarly, the diameter of area within

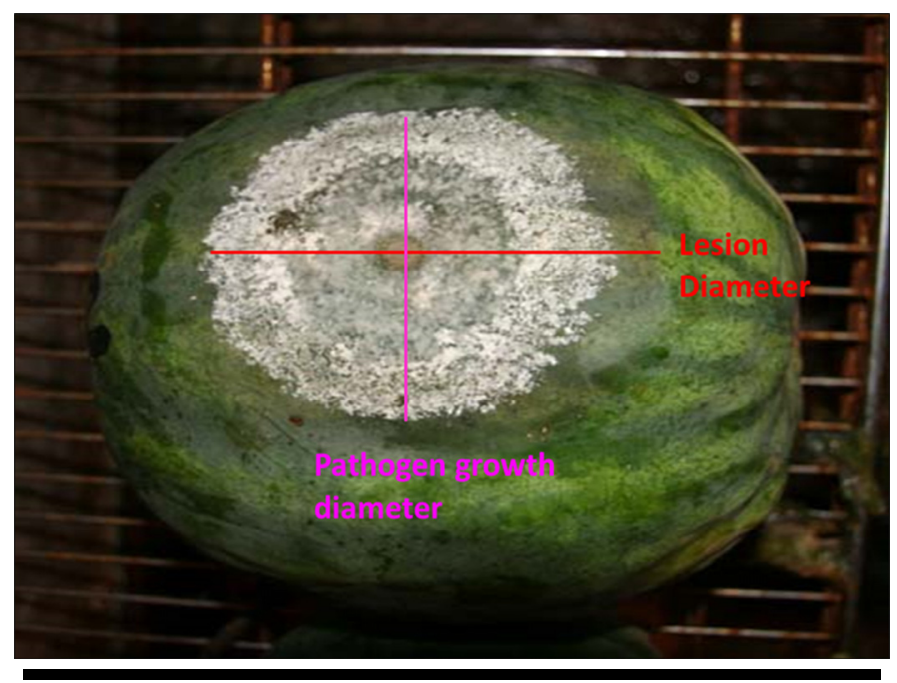

\section{FIGURE 3}

Postharvest fruit rot after inoculation and incubation in a humid chamber for five days. Abundant pathogen growth and sporulation can be observed on the fruit. The line in pink indicates the extent of visible pathogen growth and sporulation (pathogen growth diameter) on the fruit surface and the red line indicates the extent of the water soaked lesion (lesion diameter). the lesion with pathogen growth and sporangia was measured. The intensity of sporulation was recorded on a 0-5 scale, where: $0=$ no visible sporulation; 1 = sparse sporulation, few seen next to the agar plug; $2=$ some sporulation covering less than $1 / 2$ the lesion area; 3 = medium sporulation covering $1 / 2$ the lesion area; $4=$ heavy sporulation covering $3 / 4$ of the lesion area; and $5=$ abundant sporangia covering $>80 \%$ of the entire lesion area. Data on lesion diameter, pathogen growth and sporulation intensity were analyzed using PROC GLM procedures of SAS and means were separated using Fisher's protected least significant difference (LSD, $\alpha=0.05$ ) procedure of SAS. The length and width of each fruit was also measured to calculate the relative fruit rot lesion diameter (RLD) as a percentage of the fruit diameter. The RLD was used to calculate fruit rot reduction by each treatment for each year in

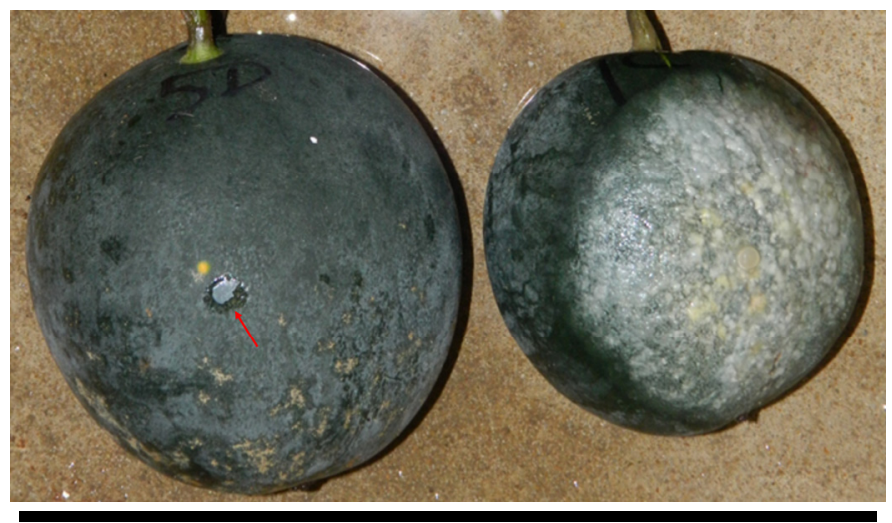

\section{FIGURE 4}

Postharvest Phytophthora fruit rot on nontreated control fruit (right) with heavy pathogen growth and sporulation compared to a fruit treated with OXTP (fruit on left) in the field. Picture was taken five days after inoculation. Fruit were inoculated with an agar plug from an actively growing colony of $P$. capsici (center of each fruit, red arrow) and maintained in a humid chamber $\left(>95 \% \mathrm{RH}, 26 \pm 2^{\circ} \mathrm{C}\right)$.

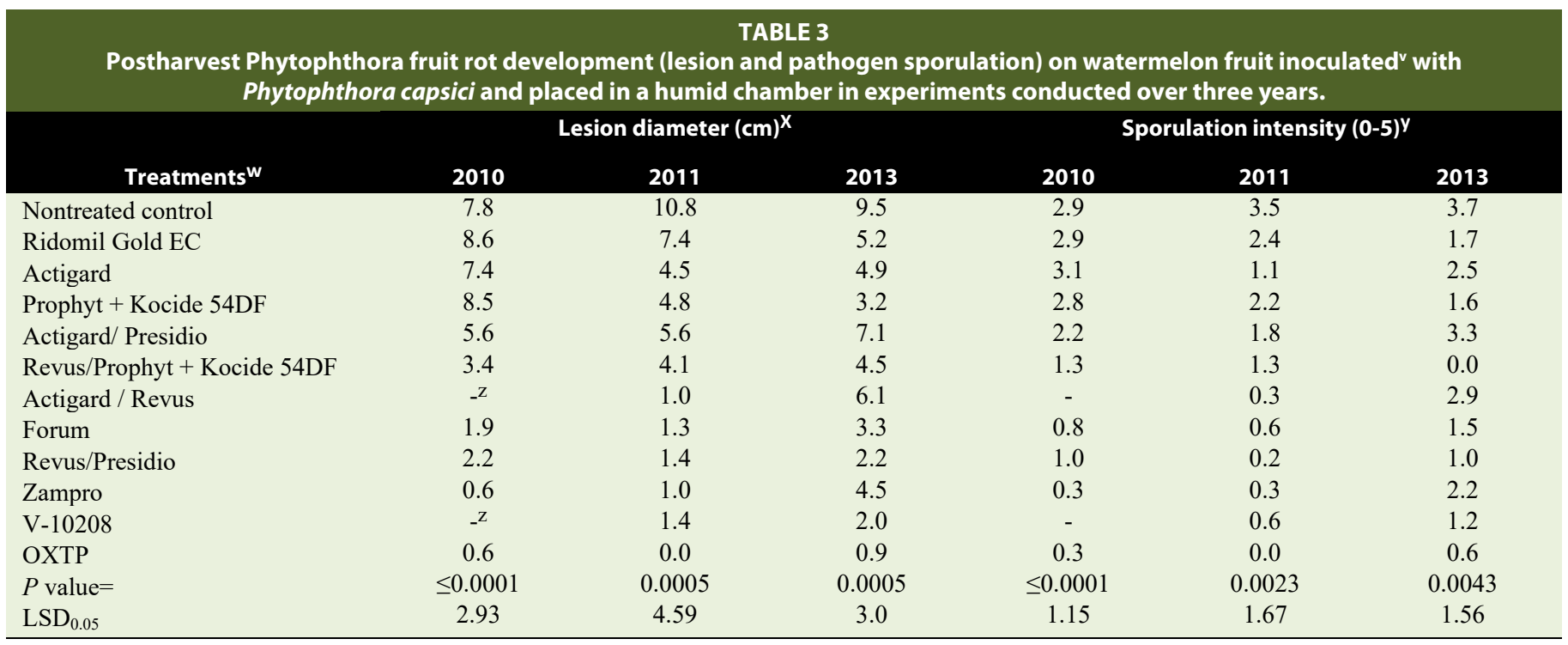

${ }^{\mathrm{V}}$ Fruit were harvested four days after last spray in the field and inoculated with a 7-mm agar plug of actively growing Phytophthora capsici. Fruit were placed in a growth room (temperature $=26 \pm 2^{\circ} \mathrm{C}$ ) and maintained at high relative humidity $(>95 \%)$ using a humidifier.

w Application rates are provided in Table 1. A " / " between two fungicides in the treatment column indicates a rotation scheme. The fungicides were alternated every week.

$\mathrm{x}$ Diameter of lesion formed on the fruit measured 5 days after inoculation.

y Intensity of sporulation within the lesion on a $0-5$ scale where $0=$ no sporulation and $5=$ heavy and intense sporulation covering $>80 \%$ of the lesion.

z V-10208 and Actigard/Revus were not evaluated in 2010. 
relation to RLD in the nontreated control for that year. Data from each year was considered as a replication to calculate the overall effectiveness of the fungicide treatments in reducing postharvest Phytophthora fruit rot lesion development.

\section{POSTHARVEST FRUIT ROT DEVELOPMENT}

In 2010, field applications of OXTP, Zampro, Forum, and rotation of Presidio with Revus protected watermelon from postharvest fruit rot even when the fruit were inoculated and kept in a warm, humid chamber that favored disease development (Table 3). The lesion diameter, pathogen growth, and sporulation intensity were significantly lower under postharvest conditions for fruit treated with these fungicides in the field. Significant positive correlation ( $r \geq 0.85, P \leq 0.0001)$ between lesion diameter, pathogen growth and sporulation intensity was observed during all three years, hence only the lesion diameter and sporulation intensity data is presented. Rotation of Revus with Prophyt + Kocide was also effective in reducing lesion diameter compared to nontreated control. However, both treatments containing Actigard and the Prophyt + Kocide treatment were not significantly different from the nontreated control in the humid chamber. In 2011, all treatments significantly reduced postharvest development of fruit rot compared to the nontreated control and Ridomil Gold. The lesion diameter, pathogen growth diameter, and the sporulation intensity were significantly lower compared to the controls for fruit treated with these fungicides. No lesions or pathogen growth was observed on fruit treated with OXTP in 2011 (Fig. 4). Similarly in 2013, OXTP was the most effective fungicide followed by V-10208 and Revus alternated with Presidio. The Actigard treatments were not very effective in reducing postharvest fruit rot compared to the nontreated control in 2013. Overall, based on three years (Table 4), OXTP, V10208, Zampro, Forum, and the rotation of Revus with Presidio provided extended postharvest protection against fruit rot for up to 9 days after the last fungicide application in the field.

\begin{tabular}{|c|c|c|c|c|}
\hline \multicolumn{5}{|c|}{$\begin{array}{l}\text { TABLE } 4 \\
\text { Postharvest fruit rot disease reduction }{ }^{\mathrm{x}} \text { due to fungicides } \\
\text { applied in the field compared to nontreated } \\
\text { control in a humid chamber conducive for Phytophthora } \\
\text { fruit rot development on watermelon. }\end{array}$} \\
\hline \multirow[b]{2}{*}{ Treatments } & \multicolumn{4}{|c|}{ Disease reduction (\%) } \\
\hline & 2010 & 2011 & 2013 & Overall \\
\hline OXTP & 92 & 100 & 85 & $92 \mathrm{a}^{\mathrm{z}}$ \\
\hline V-10208 & $-\mathrm{y}$ & 90 & 79 & $85 \mathrm{ab}$ \\
\hline Zampro & 94 & 94 & 51 & $80 \mathrm{ab}$ \\
\hline Forum & 77 & 86 & 67 & $80 \mathrm{abc}$ \\
\hline Revus/Presidio & 75 & 88 & 77 & $80 \mathrm{abc}$ \\
\hline Actigard/Revus & $-\mathrm{y}$ & 92 & 38 & $65 \mathrm{abc}$ \\
\hline Revus/Prophyt+Kocide & 56 & 69 & 59 & $61 \mathrm{bcd}$ \\
\hline Prophyt+Kocide & 12 & 61 & 69 & 47 cde \\
\hline Actigard & 15 & 61 & 44 & $40 \mathrm{de}$ \\
\hline Actigard/Presidio & 40 & 57 & 22 & 40 de \\
\hline Ridomil Gold & 0 & 39 & 48 & $29 \mathrm{de}$ \\
\hline Nontreated control & 0 & 0 & 0 & 0 \\
\hline
\end{tabular}

$\mathrm{x}$ Disease reduction was calculated as described in the text. Briefly, the relative lesion diameter (RLD) was calculated as (lesion diameter/fruit diameter $) \times 100$ for each treatment, and disease reduction $(\%)$ for each treatment was calculated on the basis of RLD for the nontreated control.

y V-10208 and Actigard/Revus were not evaluated in 2010.

${ }^{\mathrm{z}}$ Means followed by the same letter for the overall disease reduction are not significantly different based on Fisher's protected LSD $(\alpha=0.05)$.

\section{CONCLUSIONS AND MANAGEMENT IMPLICATIONS}

Watermelon plants are generally grown on plastic beds in the United States. However, most of the fruit are produced in the alley between the plastic rows. This leads to a long duration of contact between the soil and the fruit, making management of certain soil-borne pathogens particularly difficult. Furthermore, the difficulty of fungicides penetrating the thick watermelon leaf canopy to reach the area where the fruit is in contact with the soil makes management even more difficult. Results from the present study are encouraging and clearly indicate that several fungicides are currently available and effective for managing Phytophthora fruit rot in the field. In addition, several of these fungicides and simple rotations were effective in reducing postharvest fruit rot. Fruit were harvested and inoculated 4 days after the last spray treatment and kept in conditions conducive for disease development for 5 days. Despite such harsh conditions, fungicides applied in the field provided extended protection against postharvest fruit rot in storage up to 9 days after the spray treatment. It is possible that some fungicides may provide longer postharvest protection; however, additional studies are needed to determine how long such postharvest protection persists. The fungicides OXTP, Zampro, Forum, and Revus have a preharvest interval (PHI) of 0 days, and Presidio has a PHI of 2 days listed on their labels. We harvested the fruit 4 days after the last spray to meet all PHI requirements. OXTP and $\mathrm{V}-10208$ are not available to growers because they are not registered for use on watermelon, but registration and establishment of PHI for watermelon and other cucurbits is anticipated soon. It should be noted that postharvest protection was not complete due to the various fungicides in all years. A watermelon fruit will be rendered unmarketable even if the lesion is small and visible. However, the conditions we created to evaluate postharvest effectiveness were severe, and under normal circumstances the fruit rot development may be reduced. The postharvest fruit rot technique has proven effective for evaluating postharvest effectiveness of fungicides and is also routinely used for identifying genetic fruit rot resistance in watermelon $(12,13)$.

We evaluated several fungicides (OXTP, V-10208, Zampro, and Forum) without rotation to determine their effectiveness individually. However, when fungicide recommendations are made to growers it should be emphasized that these fungicides should be used in rotation schemes to manage the risk of resistance development. Most fungicide labels do state the need for rotation with other effective fungicides from different Fungicide Resistance Action Committee (FRAC) groups to prevent resistance development in the pathogen. Some even suggest tank mixing with other fungicides from different FRAC groups for resistance management. In our previous studies, several fungicides were effective in managing Phytophthora fruit rot, especially Presidio and Revus (11), and the rotation of Presidio and Revus was also effective in these studies in reducing pre- and postharvest fruit rot.

Ridomil Gold was not as effective in reducing pre- and postharvest fruit rot because mefenoxam insensitive strains were used for inoculations. Resistance to mefenoxam has been well documented throughout the United States $(4,5,8)$. Similarly, resistance to the fungicide cyazofamid was documented in $P$. capsici (10), which further indicates the need to rotate the newly developed fungicides for the management of Phytophthora fruit rot of watermelon. Even though resistance to mefenoxam is fairly wide spread it continues to be very effective against sensitive $P$. capsici populations (6), and it performed better than nontreated control in 2011 and 2013. Therefore, depending upon the sensitivity of the population to the various fungicides in any given location, it is possible that Ridomil Gold may continue to be used 
in rotation or tank mixed with other fungicides in different FRAC groups for management of Phytophthora fruit rot.

Water management is also an important strategy in managing diseases caused by $P$. capsici $(2,5,15,20)$. Apart from rotating fungicide applications, it is essential to grow watermelon in well drained fields to prevent or reduce development of Phytophthora fruit rot. Field drainage that can prevent standing water will help reduce the spread of the pathogen and the duration of contact between fruit and wet soil.

In 2013, many regions of the southeastern United States received heavy rainfall and long duration of wet soil conditions prevented growers from timely applications of fungicides to prevent and/or control disease. Some growers were able to use aircraft for fungicide applications. Despite aerial applications of recommended fungicides, several growers lost their crops due to pre- and postharvest Phytophthora fruit rot due to wet conditions and intense disease pressure. Therefore, to achieve integrated control of Phytophthora fruit rot of watermelon, fungicides must be part of an overall management strategy that at a minimum includes well drained fields, water management, and crop rotation.

\section{ACKNOWLEDGMENTS}

We acknowledge the technical assistance of Kim Alford, Lance Lawrence, and Andrew Price in conducting many of these experiments. The authors also wish to acknowledge Dr. W. P. Wechter for critical review of the manuscript. This work was supported in part by a grant from the National Watermelon Association (NWA). NWA did not take part in planning, conducting, or any other aspect of this study, including submission of this manuscript. Mention of a trademark name or proprietary product does not constitute a guarantee or warranty of the product by the U.S. Department of Agriculture, Agricultural Research Service (USDA-ARS), nor does it imply exclusion of other products that may also be suitable.

\section{LITERATURE CITED}

1. Ando, K., Hammar, S., and Grumet, R. 2009. Age-related resistance of diverse cucurbit fruit to infection by Phytophthora capsici. J. Amer. Soc. Hort. Sci. 134:176-182.

2. Babadoost, M. 2004. Phytophthora blight: A serious threat to cucurbit industries. Online. APSnet Feature, April-May 2004. doi:10.1094/APSnetFeature-2004-0404.

3. Erwin, D. C., and Riberio, O. K. 1996. Phytophthora Diseases Worldwide. American Phytopathological Society, St. Paul, MN.

4. Granke, L. L., Quesada-Ocampo, L., Lamour, K., and Hausbeck, M. K. 2012. Advances in research on Phytophthora capsici on vegetable crops in the United States. Plant Dis. 96:1588-1600.

5. Hausbeck, M. K., and Lamour, K. H. 2004. Phytophthora capsici on vegetable crops: research progress and management challenges. Plant Dis. $88: 1292-3003$.

6. Holmes, G. J. 2007. Chemical control of Phytophthora blight caused by Phytophthora capsici: A summary of field experiments in the U.S. Page 24 in: Proc. of the First Intl. Phytophthora capsici Conf., Islamorada, FL.

7. Ji, P., Koné, D., Yin, J., Jackson, K. L., and Csinos, A. S. 2012. Soil amendments with Brassica cover crops for management of Phytophthora blight on squash. Pest Manag. Sci. 68:639-644.

8. Keinath, A. P. 2007. Sensitivity of populations of Phytophthora capsici from South Carolina to mefenoxam, dimethomorph, zoxamide, and cymoxanil. Plant Dis. 91:743-748.

9. Kemble, J. M. 2010. Pages 99-102 in: Southeastern U.S. Vegetable Crop Handbook. Southeastern Vegetable Extension Workers.

10. Kousik, C. S., and Keinath, A. P. 2008. First report of insensitivity to Cyazofamid among isolates of Phytophthora capsici from the southeastern United States. Plant Dis. 92:979.

11. Kousik, C. S., Adams, M. L., Jester, W. R., Hassell, R., Harrison, H. F., and Holmes, G. J. 2011. Effect of cultural practices and fungicides on Phytophthora fruit rot of watermelon in the Carolinas. Crop Prot. 30:888-894.
12. Kousik, C. S., Ikerd, J., Wechter, W. P., Harrison, H., and Levi, A. 2012. Resistance to Phytophthora fruit rot of watermelon caused by Phytophthora capsici in U.S. Plant Introductions. HortScience 47:1682-1689.

13. Kousik, C. S., Ling, K., Adkins, S. T., Webster, C. G., and Turechek, W. 2014. Phytophthora fruit rot-resistant watermelon germplasm lines: USVL489-PFR, USVL782-PFR, USVL203-PFR, and USVL020-PFR. HortScience 49:101-104.

14. Lamour, K. H., and Hausbeck, M. K. 2000. Mefenoxam insensitivity and the sexual stage of Phytophthora capsici in Michigan cucurbit fields. Phytopathology 90:396-400.

15. McGrath, M. T. 1996. Phytophthora fruit rot. Pages 53-54 in: Compendium of Cucurbit Diseases. T. A. Zitter, D. L. Hopkins, and C. E. Thomas, eds. American Phytopathological Society, St. Paul, MN.

16. McGrath, M. T., and Menasha, S. R. 2013. Managing Phytophthora blight with biofumigation. (Abstr.) Phytopathology 103:S2.93.

17. Morrissey, B. 2006. NWA update. Pages 7-10 in: The Vineline. April 2006. National Watermelon Association, Plant City, FL.

18. Núñez-Zofío, M., Larregla, S., and Garbisu, C. 2011. Application of organic amendments followed by soil plastic mulching reduces the incidence of Phytophthora capsici in pepper crops under temperate climate. Crop Prot. 30:1563-1572.

19. Ppoyil, S. B. T. 2011. Effectiveness of mustard short-cycle cover crops for management of Phytophthora capsici and Fusarium spp. in cucurbits. MS thesis, University of Illinois, Urbana-Champaign.

20. Ristaino, J., and Johnston, S. 1999. Ecologically based approaches to management of Phytophthora blight of bell pepper. Plant Dis. 83:1080-1089.

21. Sanders, D. C. 2006. Pages 86-88 in: Southeastern U.S. Vegetable Crop Handbook. Southeastern Vegetable Extension Workers.

22. Zinati, G. N. 2005. Compost in the 20th century: A tool to control plant diseases in nursery and vegetable crops. HortTech. 15:61-66. 